\title{
Ecology of the bromeligenous frog Phyllodytes luteolus (Anura, Hylidae) from three restinga remnants across Brazil's coast
}

\author{
TATIANA MOTTA-TAVARES ${ }^{1}$, THIAGO MAIA-CARNEIRO ${ }^{1}$, LEONARDO F. DANTAS ${ }^{2}$, MONIQUE \\ VAN SLUYS ${ }^{1}$, FÁBIO H. HATANO ${ }^{3}$, DAVOR VRCIBRADIC ${ }^{4}$ and CARLOS F.D. ROCHA ${ }^{1}$ \\ ${ }^{1}$ Departamento de Ecologia, Universidade do Estado do Rio de Janeiro, Rua São Francisco Xavier, \\ 524, Pavilhão Haroldo Lisboa da Cunha, Maracanã, 20550-019 Rio de Janeiro, RJ, Brasil \\ ${ }^{2}$ Programa de Pós-Graduação em Saúde Pública e Meio Ambiente, Fundação Oswaldo Cruz, Escola Nacional de \\ Saúde Pública Sérgio Arouca, Rua Leopoldo Bulhões, 1480, Manguinhos, 21041-210 Rio de Janeiro, RJ, Brasil \\ ${ }^{3}$ Instituto Socioambiental e dos Recursos Hídricos, Universidade Federal Rural da Amazônia, \\ Av. Presidente Tancredo Neves, 2501, 66077-830 Terra Firme, Belém, PA, Brasil \\ ${ }^{4}$ Departamento de Zoologia, Instituto de Biologia, Centro de Ciências Biológicas e Saúde, Universidade \\ Federal do Estado do Rio de Janeiro, Av. Pasteur, 458, Urca, 22240-290 Rio de Janeiro, RJ, Brasil
}

Manuscript received on July 22, 2014; accepted for publication on January 16, 2015

\begin{abstract}
In this study, we analyzed diet, sexual dimorphism and bromeliad use in three populations of the hylid frog Phyllodytes luteolus from restinga habitats along the Brazilian coast. We found 13 arthropods categories in 161 stomachs. Ants and termites were the dominant prey items. The similar trophic niche across populations suggests this species has a conservative diet. We found sexual dimorphism regarding body size and jaw width. We recorded P. luteolus in five bromeliad species, but predominantly in Aechmea blanchetiana (35.6\% of individuals recorded). We recorded solitary individuals in $44 \%$ of occupied bromeliads, and never found two males sharing the same bromeliad. The data is suggestive that populations of $P$. luteolus has a conservative diet independent of area, with ants and termites the being most relevant prey items. The sexual dimorphism in jaw and the solitary males may suggest that this species have territorial behavior.
\end{abstract}

Key words: Atlantic forest, bromeliad, diet, sexual dimorphism, territorial behavior.

\section{INTRODUCTION}

Anurans commonly consume arthropods as a primary food resource (Duellman and Trueb 1986, Lima and Moreira 1993, Ferreira et al. 2012), and kinds and sizes of prey consumed may differ (Sabagh et al. 2012, Maia-Carneiro et al. 2013, Coco et al. 2014) between populations. This may be due to prey availability, which can

Correspondence to: Tatiana Motta-Tavares

E-mail: tmottatavares@gmail.com be different among areas, differences in periods of collection, altitudes, and/or phylogeny (Sabagh et al. 2012). Anurans can also use different types of microhabitat, such as leaf-litter on the forest floor, rocks, streams, ponds, lakes, trees, and bromeliads (Eterovick 1999, Almeida-Gomes et al. 2008, Duré et al. 2009, Martins et al. 2010, Ferreira et al. 2012). Bromeligenous frogs reproduce, forage and complete their entire life cycle inside bromeliads (sensu Peixoto 1995). Such dependence of bromeliads is in direct relation with species natural 
history, influencing different aspects of its ecology (Giaretta 1996, Ferreira et al. 2012, Lantyer-Silva et al. 2014).

Phyllodytes luteolus is a bromeligenous anuran species predominantly found in restinga habitats, where they inhabit tank bromeliads (Peixoto 1995, Ferreira et al. 2012). Restingas are sandy, usually open coastal habitats interspersed within the Atlantic forest biome of Brazil. Phyllodytes luteolus occurs along the Brazilian coast from the state of Paraíba southwards to the north portion of the state of Rio de Janeiro (Vrcibradic et al. 2006, Frost 2013), with the most inland record being from the state of Minas Gerais, where it occurs in some forest remnants (Feio and Caramaschi 2002). In addition, an introduced population has been recorded for the municipality of Rio de Janeiro (Salles and SilvaSoares 2010). This species is common inside bromeliads from open areas, and avoids bromeliad axils containing less than $100 \mathrm{ml}$ of water (Teixeira et al. 1997). Phyllodytes luteolus lay up to three eggs in bromeliad axils, where the larvae develop and feed on debris (Peixoto 1995, Giaretta 1996). Papp and Papp (2000) showed a drastic population reduction of $P$. luteolus after a fire in the Linhares municipality, in the state of Espírito Santo. This fire destroyed more than $99.9 \%$ of the bromeliad Vrisea neoglutinosa (Rocha et al. 1996), supporting the species strong dependence on bromeliads.

Inter-population studies regarding trophic and spatial ecology are important to explain species niche breadth, position in local trophic webs, foraging behavior, and metabolic necessities (Duellman and Trueb 1986, Toft 1980, 1981, Wells 2007). Furthermore, it enables the elucidation of whether these parameters are conservative or variable among localities. In addition, an interpopulation study about ecology and behavior of $P$. luteolus may help to elucidate how individuals correlate with each other in a limited space (the bromeliads) inside a limited habitat (the restinga remnants). The goal of this study was to investigate the diet of three populations of P. luteolus from restinga remnants, and to evaluate the relationship of frogs with the bromeliads. We specifically aimed to assess i) the differences in array of prey types consumed and trophic niche among populations, and among adult males, adult females and juveniles, ii) sexual dimorphism in body and head size in the species, and iii) the bromeliad species used by the individuals.

\section{MATERIALS AND METHODS}

\section{STUDY AREAS}

Field work was carried out between November 1999 and March 2000, in three restinga sites along the east coast of Brazil: Setiba district $\left(20^{\circ} 35^{\prime} \mathrm{S}\right.$ and $39^{\circ} 13^{\prime} \mathrm{W}$ ) in the municipality of Guarapari, Guriri district, in the municipality of São Mateus $\left(18^{\circ} 41^{\prime} \mathrm{S}\right.$ and $\left.39^{\circ} 45^{\prime} \mathrm{W}\right)$, both in the state of Espírito Santo, and one site in the municipality of Prado $\left(17^{\circ} 18^{\prime} \mathrm{S}\right.$ and $\left.39^{\circ} 13^{\prime} \mathrm{W}\right)$, in the state of Bahia (Fig. 1). The mean annual temperature on these regions is around $23{ }^{\circ} \mathrm{C}$ and the annual rainfall ranges between 1000 and $1350 \mathrm{~mm}$ (Nimer 1979). Setiba and Guriri are separated by $210 \mathrm{~km}$, whereas Guriri and Prado are $160 \mathrm{~km}$ apart, and Setiba and Prado $380 \mathrm{~km}$ apart. The bromeliad species composition varied among localities.

DATA COLLECTION AND STATISTICAL ANALYSES

We conducted diurnal and nocturnal surveys inside bromeliads through visual encounter surveys (Crump and Scott 1994) (total of 80 sampling hours). Moreover, 200 tank bromeliads of different species were randomly sampled in each area (total of 600). All individuals of $P$. luteolus found, were collected (IBAMA collection permit No. 096/99). During the collections in the field amphibians were killed with anesthetic overdose (sodium pentobarbital) as recommended by the protocols of the American Society of Ichthyologists and Herpetologists (ASIH), the Herpetologists' League (HL) (1987), the American Veterinary Medical 


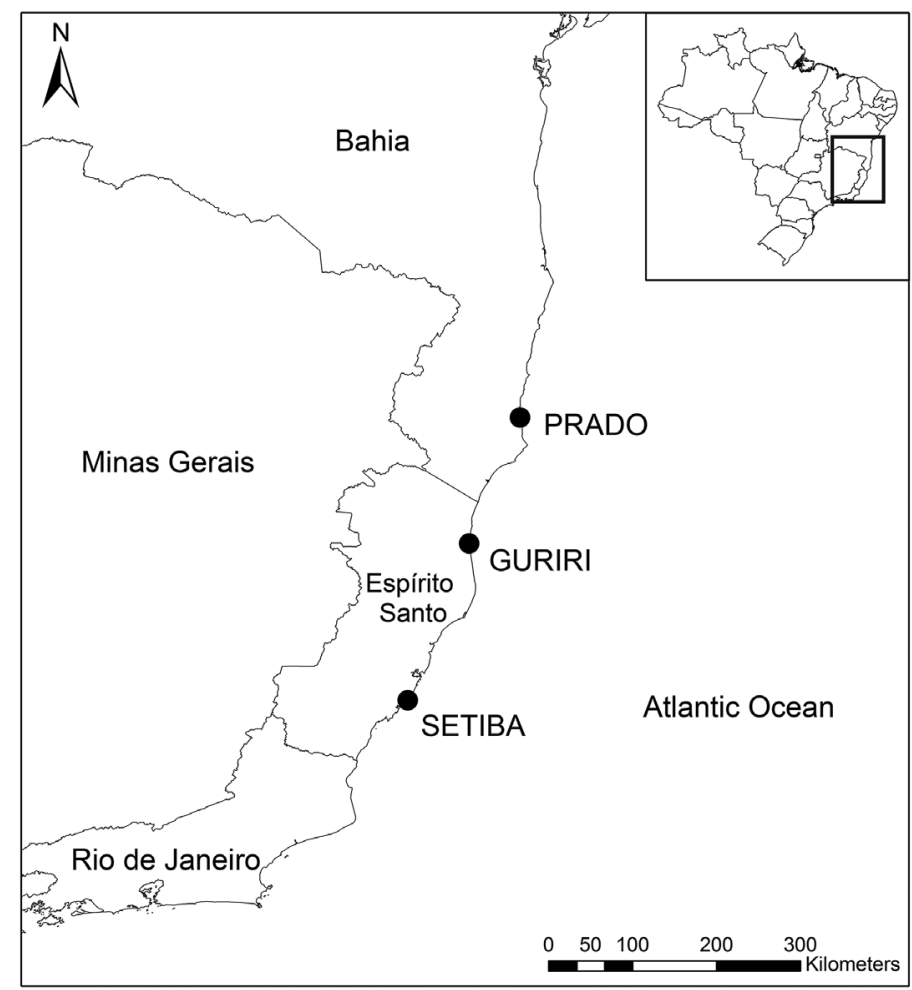

Figure 1 - Map showing restinga habitats where Phyllodytes luteolus were collected: Guriri (18 $41^{\circ} \mathrm{S}$ and $\left.39^{\circ} 45^{\prime} \mathrm{W}\right)$ and Setiba $\left(20^{\circ} 35^{\prime} \mathrm{S}\right.$ and $\left.39^{\circ} 13^{\prime} \mathrm{W}\right)$, in the state of Espírito Santo, and Prado (17 $18^{\circ} \mathrm{S}$ and $\left.39^{\circ} 13^{\prime} \mathrm{W}\right)$, in the state of Bahia.

Association (AVMA) (2000) and the Canadian Council on Animal Care (CCAC) (1993), followed by $10 \%$ formalin solution for fixation.

We measured snout-vent length (SVL) and jaw width (JW) of the frogs with calipers to the nearest $0.01 \mathrm{~mm}$. We analyzed gonads to determine sex; those individuals whose gonads were not developed were considered juveniles. We analyzed stomach contents using a stereomicroscope, and characterized the diet in terms of number of individual prey items consumed $(\mathrm{N})$, total volume of prey $\left(\mathrm{V}\right.$, in $\left.\mathrm{mm}^{3}\right)$, and frequency of occurrence $(\mathrm{F})$ of each prey category. Additionally, for each category of prey we calculated an index of importance value $\left(I_{x}\right)$ : $I_{x}$ $=\left[\left(\mathrm{n}_{\mathrm{x}} / \mathrm{N}\right)+\left(\mathrm{v}_{\mathrm{x}} / \mathrm{V}\right)+\left(\mathrm{f}_{\mathrm{x}} / \mathrm{F}\right)\right] / 3$, where $\mathrm{n}_{\mathrm{x}}, \mathrm{v}_{\mathrm{x}}$, and $\mathrm{f}_{\mathrm{x}}$ are number, volume, and frequency of prey item $\mathrm{x}$, respectively, and $\mathrm{N}, \mathrm{V}$, and $\mathrm{F}$ are summations of the number, volume, and frequency of all prey items
(Howard et al. 1999). Prey items were identified to the taxonomic level of order (or family, in the case of Formicidae). Unidentified arthropod remains and plant residues were not considered in total volumetric analysis.

We estimated the volume of each prey using the formula for an ovoid spheroid: $V=4 / 3 \pi$ (length/2) (width/2)2 (Dunham 1983). We used Pianka's overlap index (Pianka 1973) to determine the trophic niche similarity between populations:

$$
\mathrm{Ojk}=\frac{\sum_{i=1}^{n} p i j \times p i k}{\sqrt{\sum_{i=1}^{n} p i j^{2} \sum_{i=1}^{n} p i k^{2}}}
$$

where $j$ and $k$ refer to the populations under comparison and $p i$ is the proportion of prey component 
$i$. We calculated food niche overlap using the proportional values of number and volume of prey consumed. To determine if the frogs from each populations statistically differed in terms of prey consumption, we performed a one-way analysis of similarity (ANOSIM) with Bray-Curtis distance measure (Clarke 1993). We also did a nonmetric multidimensional scaling (NMDS) based on a Bray-Curtis dissimilarity matrix to compare prey consumption by each frog from each population. Mean prey volume was estimated as the mean volume of the three largest prey items consumed per frog (or all items when stomach contained less than three). We tested for differences between populations in the number of prey and in the mean prey volume consumed per frog using oneway analysis of variance (ANOVA), followed by Scheffe's post hoc test (Zar 1999) when the results were significant. We used Simple Regression Analysis between prey number and frog SVL and between mean prey volume and frog JW, to evaluate if the number of prey items or the prey volume were associated to body size and JW.

We identified the bromeliad species occupied by P. luteolus when the frog was first seen. Additionally, in Setiba and Guriri restingas, we counted the number of frogs per bromeliad, identified the ontogenetic stage (juvenile or adult) and sex, and searched for eggs and/or tadpoles in the bromeliad phytotelmata (i.e. axils and central rosette).

To assess whether there was sexual dimorphism in body size and head width of $P$. luteolus, we used one-way ANOVA for differences in SVL and in JW between males and females of each population. We used analysis of covariance (ANCOVA, with SVL as a covariate; Zar 1999) to test for differences in relative jaw width between sexes.

Descriptive statistics are presented throughout the text as mean \pm one standard deviation. All data were tested for normality and for homogeneity of variances before performing statistical analyses, and were log-transformed when necessary. We performed ANOVA and ANCOVA analysis with
Systat 11 software, and used PAST software for ANOSIM and NMDS analysis.

\section{RESULTS}

We analyzed 161 stomach content of $P$. luteolus from three restinga remnants in Brazil, of which 58 were from Setiba (27 males, 23 females, six juveniles and two unknown), 43 from Guriri (20 males, 10 females, 10 juveniles and three unknown) and 60 from Prado (29 males, 26 females, two juveniles and three unknown). A total of 21 stomachs were empty of which: five were from Setiba $(8.6 \%$; two males, three females), 14 from Guriri (32.6\%; 10 males, two females, two juveniles), and two were from Prado (3.3\%; one male, one juvenile). Thirteen different arthropod categories were found in the stomachs (Table I). Formicidae and Isoptera were the most numerous and frequent prey (Table I). These two taxa accounted for more than $90 \%$ of prey consumed in each population, and were the most important (Ix) prey items. Isoptera represented the highest proportional volume in the stomachs (55.2\% in Setiba, 53.0\% in Guriri; $43.0 \%$ in Prado), followed by Formicidae (19.3\% in Setiba; $16.4 \%$ in Guriri; 38.7\% in Prado).

There was no difference in the mean number of prey items consumed by males, females and juveniles of $P$. luteolus (ANOVA, $\mathrm{F}_{2,118}=1.350, \mathrm{P}=$ 0.263 ; Table II). The mean volume of prey ingested differed among males, females and juveniles (ANOVA, $\mathrm{R}^{2}=0.091, \mathrm{~F}_{2,117}=5.890, \mathrm{P}=0.004$ ). Juveniles ingested smaller prey compared to males (Scheffe, $\mathrm{P}=0.019$ ), and females (Scheffe, $\mathrm{P}=0.004)$. There was no difference in the mean volume of prey consumed between adult males and females (Scheffe, $\mathrm{P}=0.639$ ).

The number of prey items consumed per frog was not related to frog SVL in any population (Regression Analysis, Setiba: $F_{145}=3.133, \mathrm{P}=$ 0.083, Guriri: $\mathrm{F}_{1,45}=3.133, \mathrm{P}=0.956$, and Prado: $\left.\mathrm{F}_{1,53}=0.499, \mathrm{P}=0.483\right)$. For Setiba population, the volume of prey was influenced by JW (Regression 


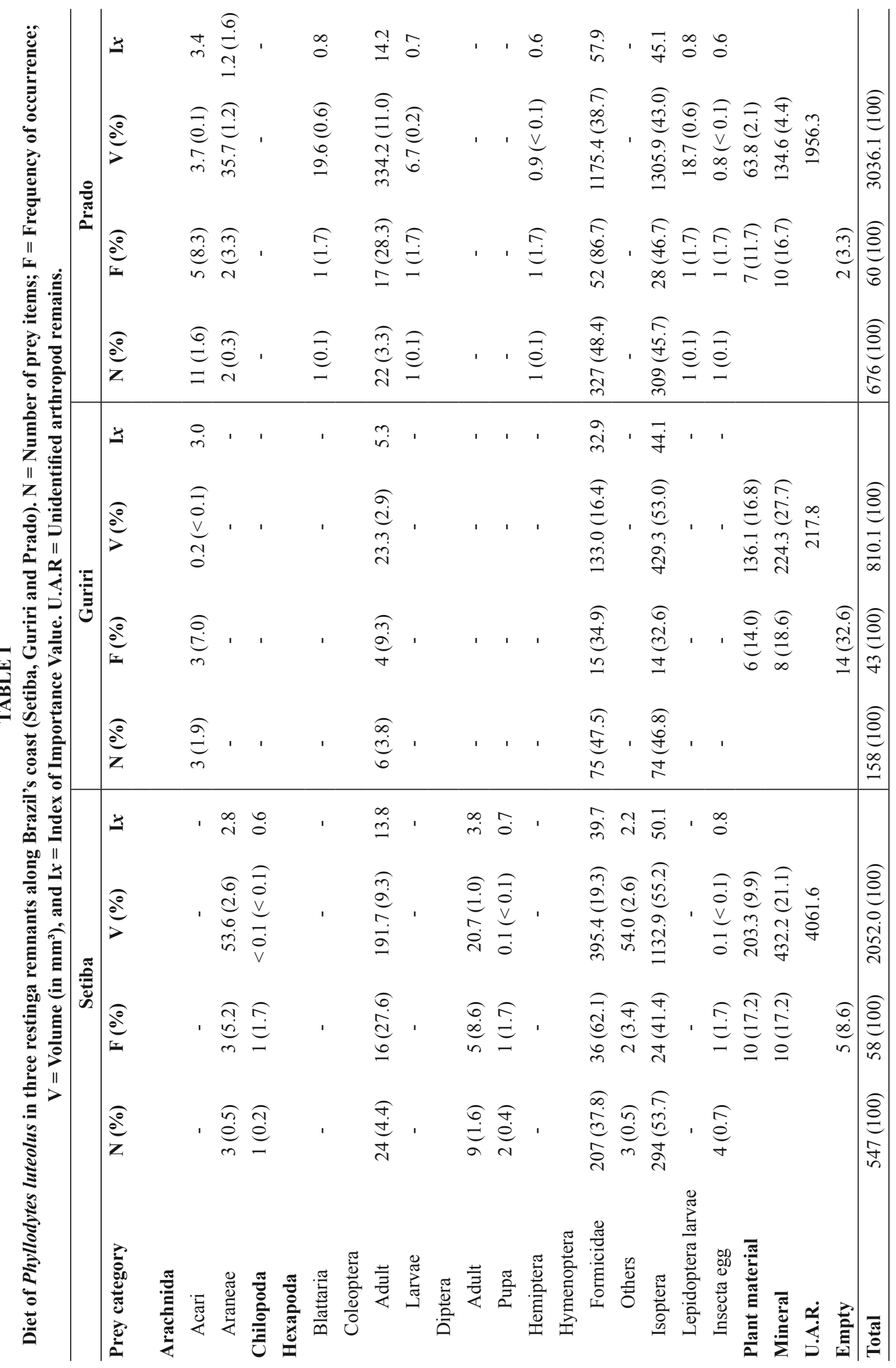


TABLE II

Number of prey and prey volume $\left(\mathrm{mm}^{3}\right)$ per stomach for males, females and juveniles of Phyllodytes luteolus in three restinga remnants along Brazil's coast. SD $=$ Standard deviation

\begin{tabular}{lcccc}
\hline & \multicolumn{2}{c}{ Number of prey } & \multicolumn{2}{c}{ Prey volume } \\
\hline & Mean $\pm \mathrm{SD}$ & Range & Mean \pm SD & Range \\
\hline Males $(\mathrm{N}=57)$ & $9.8 \pm 8.8$ & $1-41$ & $5.4 \pm 7.1$ & $0.1-30.7$ \\
Females $(\mathrm{N}=49)$ & $14.0 \pm 15.8$ & $1-71$ & $5.9 \pm 6.6$ & $0.03-30.5$ \\
Juveniles $(\mathrm{N}=15)$ & $6.8 \pm 5.1$ & $1-16$ & $1.8 \pm 2.3$ & $0.04-6.8$ \\
Total $(\mathrm{N}=121)$ & $11.1 \pm 12.0$ & $1-71$ & $5.2 \pm 6.6$ & $0.03-30.7$ \\
\hline
\end{tabular}

Analysis, $\left.\mathrm{F}_{1,45}=19.876, \mathrm{R}^{2}=0.31, \mathrm{P}<0.0001\right)$. In Prado population, the volume of prey had a nearly significant influence by JW $\left(\mathrm{F}_{1,45}=3.778\right.$, $\mathrm{P}=0.057)$, but Guriri's population showed no relationship $\left(\mathrm{F}_{1,20}=1.781, \mathrm{P}=0.197\right)$.

There was no difference in the mean number of prey items per stomach among P. luteolus populations (ANOVA, $\mathrm{F}_{2,121}=0.694, \mathrm{P}=0.502$ ). The mean volume of the three largest prey ingested per frog differed among populations (ANOVA, $F_{2,121}$ $=3.757, \mathrm{P}=0.026)$. Frogs from Prado consumed larger prey than frogs from Setiba (Scheffe, $\mathrm{P}=$ 0.025 ) but not from Guriri (Scheffe, $\mathrm{P}=0.193$; Fig. 2). Prey ingested by frogs from Setiba and Guriri did not differ in mean volume (Scheffe, $\mathrm{P}=0.947$ ).

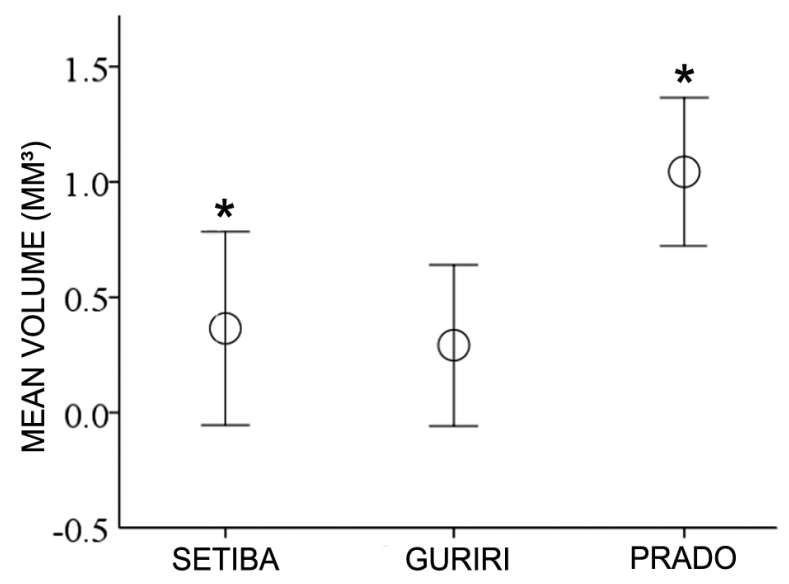

Figure 2 - Mean volume (log-transformed) of the three largest prey items ingested per stomach of Phyllodytes luteolus in three remnants restinga along the eastern coast of Brazil (Setiba, Guriri and Prado). The asterisk means that the volume of prey consumed was significantly different between these populations. Sample sizes: Setiba $=47$, Guriri $=22$ and Prado $=55$.
The food niche overlap among populations was high, both in terms of numerical and volumetric proportions of prey items, with values of 0.90 or higher in all cases (Table III). The ANOSIM indicated divergence in prey consumption between populations, but with an $\mathrm{R}$ close to zero $(\mathrm{R}=0.0470$, $\mathrm{P}=0.0195$ ). Prado population had the most divergent prey consumption in comparison with the others (ANOSIM, Prado vs. Setiba: $\mathrm{R}=0.0567, \mathrm{P}=0.0118$; Prado vs. Guriri: $\mathrm{R}=0.0895, \mathrm{P}=0.0466$ ). Setiba and Guriri populations had similar prey consumption (ANOSIM, $\mathrm{R}=-0.0415, \mathrm{P}=0.8687$ ). The prey consumption between individuals (Fig. 3) can be interpreted as similar, with just a few individuals from Prado standing out $($ stress $=0.1148)$.

TABLE III

Diet niche overlap for Phyllodytes luteolus in three remnants of restinga along the Brazilian coast based on proportional values of prey items and prey volume.

\begin{tabular}{ccc}
\hline & Prey items & Prey volume \\
\hline Setiba x Guriri & 0.98 & 0.99 \\
Guriri x Prado & 0.99 & 0.90 \\
Prado x Setiba & 0.98 & 0.99 \\
\hline
\end{tabular}

Female were larger (SVL) than males in Prado (ANOVA, $\mathrm{R}^{2}=0.31, \mathrm{~F}_{1,55}=24.801, \mathrm{P}<0.0001$ ), but not in Setiba (ANOVA, $\mathrm{F}_{1,46}=0.033, \mathrm{P}=0.856$ ) nor in Guriri (ANOVA, $\mathrm{F}_{1,28}=2.785, \mathrm{P}=0.106$ ) (Table IV). Across the populations, males had comparatively wider jaws than females, irrespective of body size: Setiba - ANCOVA, $\mathrm{R}^{2}=0.589, \mathrm{~F}_{1,1,45}=$ 47.220, $\mathrm{P}<0.0001$, Guriri - ANCOVA, $\mathrm{R}^{2}=0.710$, 


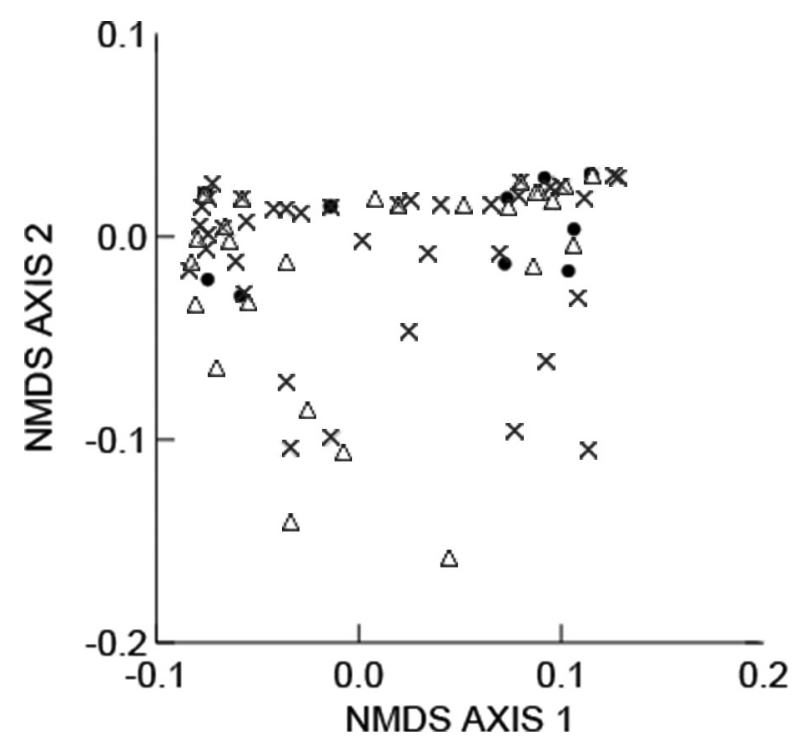

Figure 3 - Multidimensional scaling analyses of the diet composition in individuals of Phyllodytes luteolus from Setiba (empty triangles), Guriri (filled dots) and Prado ("X"). Stress $=0.1148$.

$\mathrm{F}_{1,1,27}=63.984, \mathrm{P}<0.0001$, Prado - ANCOVA, $\mathrm{R}^{2}$ $=0.922, \mathrm{~F}_{1,1,54}=480.146, \mathrm{P}<0.0001$.

Phyllodytes luteolus was found in five bromeliad species (Table V), where in 135 bromeliads $(22.5 \%)$ were occupied by at least one P. luteolus. We recorded 102 (25.5\%) bromeliads containing individuals of $P$. luteolus in Setiba and Guriri. In 45 of them (44.1\%) we found only one individual of $P$. luteolus inside the bromeliad, of which 28 (27.4\%) were males and 17 (16.6\%) were females. Four individuals (one male, one female and two of unknown sex; each one in a different bromeliad) were found with clutches containing a maximum of six eggs. In 57 of the 102 bromeliads containing P. luteolus (55.9\%), two to four individuals were found inside the same bromeliad. In none of the cases, males were found sharing a bromeliad, but males co-occurred with females, juveniles and/or tadpoles. In the 14 cases in which tadpoles were present inside bromeliads, there were one to six tadpoles and, in most cases, at least one frog inside the same bromeliad (11 females, four males, one juvenile, and two of unknown sex).

\section{DISCUSSION}

The three populations of $P$. luteolus had a diet composed exclusively of arthropods. The diet was composed of a relatively wide variety of prey types, but Formicidae and Isopteras dominated the prey consumed. Similarly, in the restinga of Regência in the state of Espírito Santo, Ferreira et al. (2012) reported on a population of P. luteolus that fed on 19 different prey types, with Formicidae and Isoptera being the most important prey. Due to the high proportion of Formicidae and Isoptera consumed, these authors suggested that $P$. luteolus had a specialized diet, predominantly composed of colonial arthropods. Because specialization in diet is a result of evolution, we consider Formicidae and Isoptera as prey preferentially consumed. Apparently, P. luteolus has a conservative diet across sites, independently of local peculiarities and differences among sites. It is possible that access to Formicidae and Isoptera might be facilitated in microhabitats that accumulate plant remains, like the interior of some tank bromeliads. Formicidae is commonly associated with bromeliads (Schimd et al. 2010), which may facilitate them being found and subsequent consumption by frogs. Toft (1980, 1981) suggests the use of Jacob's elective index to evaluate if a species has a specialized diet, based on prey abundances in the habitat and in the stomachs. Thus, to better infer if the diet of P. luteolus is specialized or generalized, it would be necessary to evaluate whether frogs select prey items or if they consume them according to prey availability inside bromeliads. However, in the absence of specific studies on the arthropod fauna inside bromeliads, at the study sites, we were not able to confirm to what extent $P$. luteolus specializes in colonial insects. The presence of plant remains and sand in the diet of $P$. luteolus was considered accidental ingestion. The difference of empty stomachs between populations may be due to prey availability at the moment of the fieldwork in each locality. 


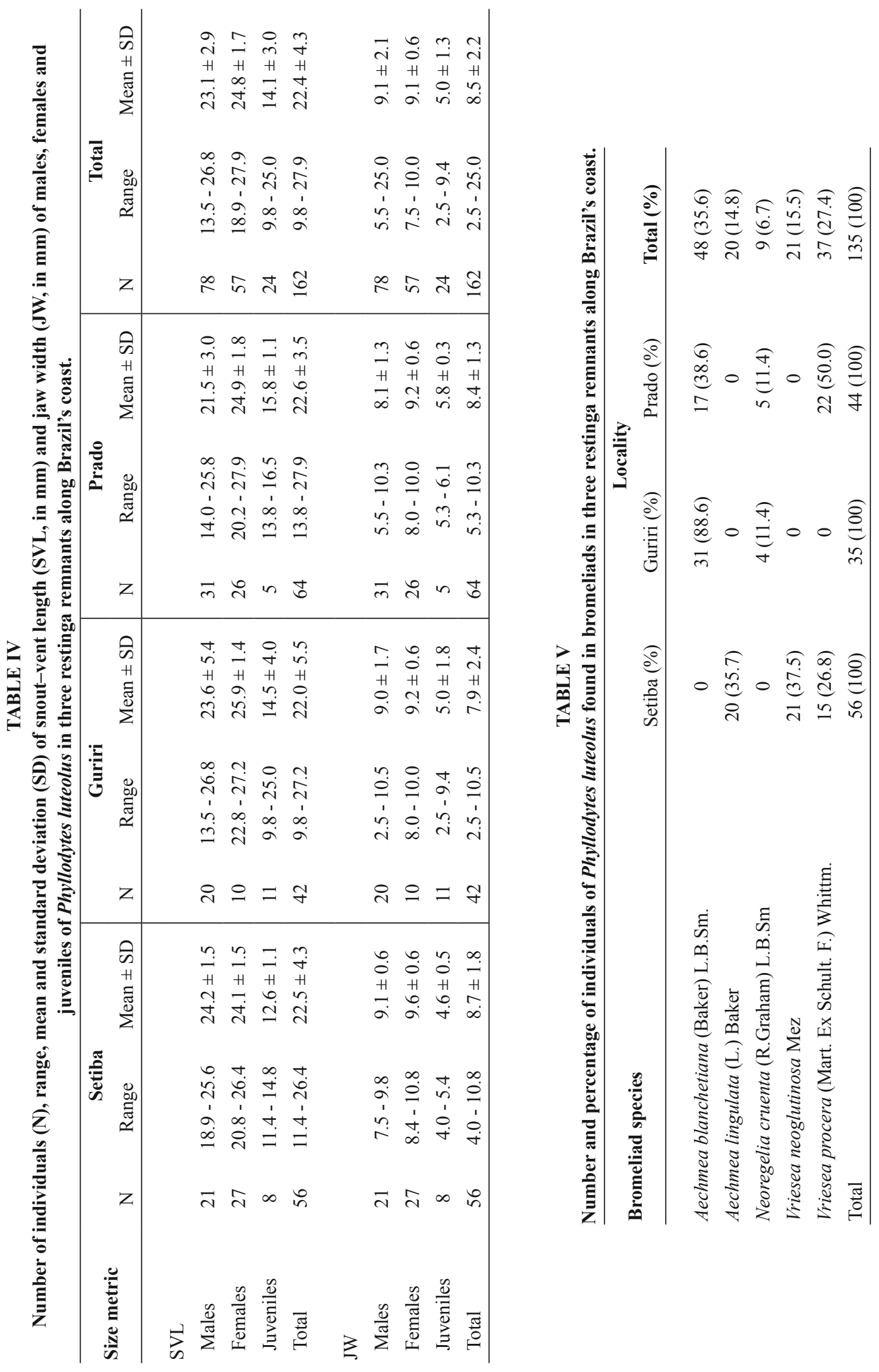


Such as expected, we observed that juveniles of P. luteolus tended to consume smaller prey compared to adults. Anurans ingest prey with size proportional to their JW, thus consuming larger prey as their jaw size increases (e.g. Lima and Moreira 1993, Marra et al. 2004, Dietl et al. 2009, Martins et al. 2010). Smaller preys should be less energetically profitable for adults, and the consumption of larger prey should result in a greater amount of energy.

There were some inter-population differences in the mean volume of prey items consumed by P. luteolus. The volume of prey consumed may have differed due to variation in prey availability among the studied restingas. The distance between sites might explain the variation in the volume of prey consumed. For instance, a study with Rhinella ornata (Spix, 1824) in three different localities (which are at least $27 \mathrm{~km}$ distance from each one) revealed that the populations differed with regard to the number and volume of prey consumed by individuals, but with a more similar diet between the areas closest to each other and with similar environments (Maia-Carneiro et al. 2013).

Despite considerable distances between populations $(>150 \mathrm{~km})$, trophic niches of $P$. luteolus were very similar (at least $90 \%$ overlap in all cases). The probality of significance in the ANOSIM demonstrates a significant difference between populations, but the $\mathrm{R}$ close to 0 indicates similar prey consumption. The similarity between populations is reinforced by observation of the NMDS outcomes in Figure 3. These ANOSIM results can be due to the divergence of Prado from others sites, or the analyzed factor (prey consumption) was a weak factor. Two explanations of extensive diet overlap between the populations are: i) similar arthropod faunas inhabiting bromeliads in the studied restingas, or ii) an inherent preference for Formicidae and Isoptera is characteristic of P. luteolus. Evaluation of our data together with those available in the literature (Ferreira et al. 2012) suggests that $P$. luteolus has some degree of conservatism regarding its trophic niche, feeding on similar prey types (mainly Formicidae and Isoptera) independent of local patterns of prey supply in different sites.

Females were larger than males in the Prado population, which is consistent with observations for congeneric species (e.g. P. wuchereri, Caramaschi et al. 2004; P. maculosus, Cruz et al. 2006). A possibility for the absence of dimorphism in body size in the other two populations may be due to sample size. Overall, females tend to be larger than males in most anuran species (Shine 1979). This difference in body size occurs due to intra-sexual selection that favors larger relative body size of females, which is linked to a capacity to produce larger clutch sizes or larger eggs (Duellman and Trueb 1986, Martins et al. 2010).

Because no more than one adult male was found in the same bromeliad and male P. luteolus have larger proportional jaw widths than females, we propose that males of this species may have territorial behavior. Eterovick (1999) did not record territorial behavior in P. luteolus, contrary to Weygoldt (1981), who observed agonistic interactions among males under laboratory conditions. Teixeira et al. (1997) suggested that intra-specific competition among males (e.g. for females, preys, shelters and/ or reproductive sites) occurs in P. luteolus, and Weygoldt (1981) proposed that the low density of adults per bromeliad suggests that males of this species exhibit intra-specific territorial behavior. In the Brazilian restinga of Regência, two studies also found a high percentage of solitary P. luteolus inside bromeliads (individuals were not categorized by sex) - Schineider and Teixeira (2001) observed that up to $80 \%$ of individuals were found alone within a bromeliad depending on the bromeliad species, and Ferreira et al. (2012) found that $65 \%$ of examined bromeliads had only one P. luteolus. 
Sexual dimorphism in JW (males having relatively larger jaws than females) also suggests territorial behavior. Males of $P$. luteolus use mandibular odontoids during fights (Weygoldt 1981, Duellman and Trueb 1986), and males with larger jaws are presumably more successful during territorial struggles.

Despite the consumption of a relatively wide array of prey, particular food items, such as colonial insects (ants and termites) for Phyllodytes luteolus, might predominantly compose the diet of species. Although may occur intra- and inter-population differences in types and sizes of preys consumed by $P$. luteolus, in some cases these parameters might be conservative. Sexual dimorphism in size jaw width and body size, with males having proportionally larger jaws than females and with females larger-sized than males, might confer an advantages during territorial interactions in males and favor greater fecundity in females.

\section{ACKNOWLEDGMENTS}

We are grateful to G.R. Winck for preparing the map. Special thanks to J.H.F. Mello, K. Welsh, M. Almeida-Gomes and the anonymous reviewers for the contributions to the manuscript. We are greatful to V.N.T. Borges-Jr. for helping with the statistical analysis. We also thank K. Welsh for the English revision. This study was supported by research grants from the Conselho Nacional de Desenvolvimento Científico e Tecnológico (CNPq) to C.F.D. Rocha (processes 304791/2010-5 and 472287/2012-5) and to M. Van Sluys (processes CNPq 301401/2002-7 and 307773/2008-6); from the Fundação Carlos Chagas Filho de Amparo à Pesquisa do Estado do Rio de Janeiro (FAPERJ) through "Cientistas do Nosso Estado" Program (process E-26/102.765.2012) to C.F.D. Rocha. T. Motta-Tavares and L.F. Dantas received undergraduate fellowships from CNPq. T. Maia-Carneiro received $\mathrm{PhD}$ scholarship from Coordenação de Aperfeiçoamento de Pessoal de Nível Superior (CAPES) and from FAPERJ. We thank IBAMA for the collection permit (No. 096/99).

\section{RESUMO}

Neste estudo, analizamos a dieta, dimorfismo sexual e uso de bromélias em três populações do hilídeo Phyllodytes luteolus de habitats de restinga ao longo da costa brasileira. Encontramos 13 categorias de artrópodes em 161 estômagos. Formigas e cupins foram as presas dominantes. O nicho trófico semelhante registrado entre as populações sugere que essa espécie possui uma dieta conservativa. Encontramos dimorfismo sexual referentes ao tamanho do corpo e largura da mandíbula. Observamos $P$. luteolus em cinco espécies de bromélias, mas predominantemente em Aechmea blanchetiana (35.6\% dos indivíduos encontrados). Encontramos indivíduos solitários em $44 \%$ das bromélias ocupadas, e nunca dois machos dividindo a mesma bromelia. Os dados sugerem que as populações de P. luteolus possuem uma dieta conservadora independente da localidade, com formigas e cupins como as presas mais relevantes. O dimorfismo sexual no tamanho das mandíbulas e os machos solitários podem sugerir que esta espécie possui comportamento territorial.

Palavras-chave: Mata Atlântica, bromélia, dieta, dimorfismo sexual, comportamento territorial.

\section{REFERENCES}

ALMEIDA-GOMES M ET AL. 2008. Herpetofauna of an Atlantic rainforest area (Morro São João) in Rio de Janeiro State, Brazil. An Acad Bras Cienc 80: 291-300.

CARAmaschi U, PEIXOTO OL AND Rodrigues MT. 2004. Revalidation and redescription of Phyllodytes wuchereri (Peters, 1873) (Amphibia, Anura, Hylidae). Arq Mus Nac 62: 185-191.

CLARKE KR. 1993. Nonparametric multivariate analyses of changes in community structure. Aust J Ecol 18:117-143.

COCO L, BORGES-JUNIOR VNT, FUSINATTO LA, KIEFER MC, OLIVEIRA JC, ARAUJO PG, COSTA BM, VAN SLUYS M AND RoCHA CFD. 2014. Feeding habits of the leaf litter frog Haddadus binotatus (Anura, Craugastoridae) from two Atlantic Forest areas in southeastern Brazil. An Acad Bras Cienc 86: 239-249.

CRUMP ML AND SCOTT JR NJ. 1994. Visual encounter surveys. In: Heyer WR et al. (Eds), Measuring and Monitoring Biological Diversity: Standard Methods for 
Amphibians, Washington D.C.: Smithsonian Institution Press, USA, p. 84-92.

CRUZ CAG, FEIO RN AND CARDOSO MCS. 2006. Description of a new species of Phyllodytes Wagler, 1830 (Anura, Hylidae) from Atlantic Forest of the states of Minas Gerais and Bahia, Brazil. Arq Mus Nac 64: 321-324.

DietL J, ENGELS W AND SOLÉ M. 2009. Diet and feeding behaviour of the leaf-litter frog Ischnocnema henselii (Anura: Brachycephalidae) in Araucaria rain forests on the Serra Geral of Rio Grande do Sul, Brazil. J Nat Hist 43(23): 1473-1483.

DUELLMAN WE AND TRUEB L. 1986. Biology of amphibians. $2^{\mathrm{a}}$ ed., Baltimore and London: McGraw-Hill, $670 \mathrm{p}$.

DUNHAM AE. 1983. Realized niche overlap, resource abundance and intensity of interspecific competition in lizard ecology. In: Huey RD, Pianka ER and Schoener TW (Eds), Lizards Ecology: Studies of Model Organism, Cambridge: Harvard University Press, USA, p. 261-280.

DURÉ MI, KEHR AI AND SCHAEFER EF. 2009. Niche overlap and resource partitioning among five sympatric bufonids (Anura, Bufonidae) from northeastern Argentina. Phyllomedusa 8(1): 27-39.

ETEROVICK PC. 1999. Use and sharing of calling and retreat sites by Phyllodytes luteolus in a modified environment. J Herpetol 1(1): 17-22.

FEIO RN AND CARAMASCHI U. 2002. Contribuição ao conhecimento da herpetofauna do nordeste do estado de Minas Gerais, Brasil. Phyllomedusa 1(2): 105- 111.

FERREIRA RF, SCHINEIDER JAP AND TEIXEIRA RL. 2012. Diet, fecundity and use of bromeliads by Phyllodytes luteolus (Anura: Hylidae) in southeastern Brazil. J Herpetol 46(1): 19-24.

FROST DR. 2013. Amphibian Species of the World: an Online Reference. Version 5.6 (January 9, 2013). Electronic Database accessible at http://research.amnh.org/ herpetology/amphibia/index.html. American Museum of Natural History, New York.

GIARETTA AA. 1996. Reproductive specializations of the bromeliad hylid frog Phyllodytes luteolus. J Herpetol 30(1): 96-97.

HOWARD AK, FORESTER JD, RUDER JM, PARMERLEE JR JS AND POWELL R. 1999. Natural history of a terrestrial Hispaniolan anole: Anolis barbouri. J Herpetol 4(33): 702706.

LANTYER-SILVA ASF, SOLÉ M AND ZINA J. 2014. Reproductive biology of a bromeligenous frog endemic to the Atlantic Forest: Asparasphenodon arapapa Pimenta, Napoli and Haddad, 2009 (Anura: Hylidae). An Acad Bras Cienc 86: 865-880.

LIMA AP AND MOREIRA G. 1993. Effects of prey size and foraging mode on the ontogenetic change in feeding niche of Colostethus stepheni (Anura: Dendrobatidae). Oecologia 95(1): 93-102.

MAIA-CARNEIRO T, KIEFER MC, VAN SLUYS M AND ROCHA CFD. 2013. Feeding habits, microhabitat use, and daily activity period of Rhinella ornata (Anura, Bufonidae) from three Atlantic rainforest remnants in southeastern Brazil. North-West J Zool 9(1): 157-165.

MARRA RV, VAN SLUYS M AND ROCHA CDF. 2004. Food habits of Eleutherodactylus parvus (Anura: Leptodactylidae) at Atlantic rainforest area, Southeastern Brazil. Herpetol Rev 35(2): 135-137.

MARTINS ACJS, KIEFER MC, SIQUEIRA CC, VAN SLUYS M, MENEZES VA AND ROCHA CFD. 2010. Ecology of Ischnocnema parva (Anura: Brachycephalidae) at the Atlantic rainforest of Serra da Concórdia, state of Rio de Janeiro, Brazil. Zoologia 27(2): 201-208.

NIMER E. 1979. Climatologia do Brasil. Instituto Brasileiro de Geografia e Estatística, Rio de Janeiro, 421 p.

PAPP MG AND PAPP COG. 2000. Decline in a population of the treefrog Phyllodytes luteolus after fire. Herpetol Rev 31(2): 93-95.

PEIXOTO OL. 1995. Associação de anuros a bromeliáceas na Mata atlântica. Rev Univ Rural. Sér Ciênc da Vida 17(2): $75-83$.

PIANKA ER. 1973. The structure of lizard communities. Annu Rev Ecol Syst 4: 53-74.

ROCHA CFD, VAN SLUYS M, ORNELlAS AB, SIQUEIRA AE, CONDE CFV, BITTENCOURT EB, OLIVEIRA MGN, BARRos MC AND MAGALHÃES SAP. 1996. The effects of fire on natural populations of Vrisea neoglutinosa in a relict restinga of Espírito Santo state. Bromélia 3: 16-26.

SABAGH LT, CARVALHO-E-SILVA AMPT AND ROCHA CFD. 2012. Diet of the toad Rhinella icterica (Anura: Bufonidae) from Atlantic Forest Highlands of southeastern Brazil. Biota Neotrop 12(4): 258-262.

SAlles RDOL AND SILVA-SoARes T. 2010. Phyllodytes luteolus (Anura, Hylidae) as an alien species in the Rio de Janeiro municipality, state of Rio de Janeiro, Southeastern Brazil. Herpetol Notes 3: 257-258.

SCHMID VS, SCHMID S, STEINER J AND ZILLIKENS A. 2010. High diversity of ants foraging on extrafloral nectar of bromeliads in the Atlantic rainforest of southern Brazil. Stud Neotrop Fauna E 45(1): 39-53.

SCHINEIDER JA AND TEIXEIRA RL. 2001. Relacionamento entre anuros e bromélias da restinga de Regência, Linhares, Espírito Santo, Brasil. Iheringia, Sér Zool, Porto Alegre 91: 41-48.

SHINE R. 1979. Sexual selection and sexual dimorphism in the Amphibia. Copeia 1979: 297-306.

TEIXEIRA RL, ZAMPROGNO C, ALMEIDA GI AND SCHINEIDER JAP. 1997. Ecological topics of Phyllodytes luteolus (Amphibia: Hylidae) in a Sandy coastal plain of São Mateus, Espírito Santo state. Rev Bras Biol 57(4): 647-654.

TOFT CA. 1980. Seasonal variation in populations of Panamanian litter frogs and their prey: a comparison of wetter and drier sites. Oecologia 47: 34-38.

TOFT CA. 1981. Feeding ecology of Panamanian litter anurans: patterns in diet and foraging mode. J Herpetol 15: 139-144. 
VRCIBRADIC D, HATANO FH, ROCHA CFD AND VAN SLUYS M. 2006. Geographic distribution: Phyllodytes luteolus. Herpetol Rev 37: 489.

WELLS KD. 2007. The Ecology and Behavior of Amphibians. Chicago: The University Chicago Press, USA, 1400 p.
WEYGOLDT P. 1981. Beobachtungen zur Fortplanzurngsbiologie von Phyllodytes luteolus (Wied, 1824) im Terrarium. Salamandra 17(1/2): 1-11.

ZAR JH. 1999. Biostatistical Analysis, $4^{\text {th }}$ ed., New Jersey: Prentice Hall, USA, 663 p. 